\title{
Personalized Cancer Medicine: From Molecular Diagnostics to Targeted Therapy with Natural Products
}

Author

Affiliation
Thomas Efferth

Department of Pharmaceutical Biology, Institute of Pharmacy and Biochemistry, University of Mainz, Mainz, Germany
Key words

- chemotherapy

- comparative genomic hybridization

- drug resistance

- pharmacogenomics

- pharmacognosy

traditional Chinese medicine

\section{Abstract \\ $\nabla$}

Personalized cancer medicine aims to develop individualized treatment options adapted to factors relevant for the prognosis of each patient. Molecular biomarkers are required to predict the likelihood of an individual tumor's responsiveness or of toxicity in normal organs and to advise optimized treatments with improved efficacy at reduced side effects for each cancer patient. In the present review, we present a concept, which takes advantage of methods of molecular diagnostics to identify predictive markers at the DNA, mRNA, and protein levels. Markers with prognostic value concerning treatment response and patient survival can then be used as targets to develop optimized drugs. We focus on three examples to illustrate this strategy: (i) chemoselective treatment of tumors with 9p21 deletion by L-alanosine, (ii) treatment of multidrug-resistant P-glycoproteinexpressing tumor cells by non-cross-resistant natural products or by inhibitors of P-glycoprotein to overcome multidrug resistance, and (iii) natural products that inhibit the epidermal growth factor receptor (EGFR) in EGFR-overexpressing tumor cells. received February 8, 2010 revised April 15, 2010 accepted April 19, 2010

\section{Bibliography}

Dol http://dx.doi.org/

10.1055/s-0030-1249937

Published online May 19, 2010

Planta Med 2010; 76:

1143-1154 @ Georg Thieme

Verlag KG Stuttgart · New York ·

ISSN 0032-0943

\section{Correspondence}

Thomas Efferth

Department of Pharmaceutical Biology

Institute of Pharmacy and

Biochemistry

University of Mainz

Staudinger Weg 5

55128 Mainz

Germany

Phone: + 4961313925751

Fax: + 4961313923752

efferth@uni-mainz.de
Molecular Diagnostics of Prognostic Markers

$\nabla$

Resistance to chemotherapy and the concept of individualized treatment

The basis of multicomponent cancer therapy is the view that cancer cells resistant to one drug remain susceptible to other drugs. Clinically, the success of combination treatments is frequently limited due to the development of broad-spectrum or multidrug resistance (MDR). Since most established cytostatic drugs lack sufficient tumor specificity, normal tissues are also affected leading to severe side effects. This prevents the application of sufficiently high doses to kill resistant tumor cells or resistant tumor stem cells. Thereby, drug resistance develops causing treatment failure. Novel strategies to broaden the narrow therapeutic range by separating the effective dose and toxic dose would be of great benefit for the patients.

Whereas the statistical probability of therapeutic success is well-known for larger groups of patients from clinical therapy trials, it is, however, not possible to predict how an individual tumor will respond to chemotherapy. The question arises as to which particular cytostatic agent and which combination of substances is most suited for an individual tumor. Although clinicopathological prognostic factors such as tumor size, lymph node, and far distance metastases are valuable for the determination of the prognosis of larger cohorts, they are less helpful for individualized cancer treatment. Further biomarkers are required to predict the likelihood of an individual tumor's responsiveness or of toxicity in normal organs of each patient.

Clinically, it has been known for many years that the same doses of a medication cause considerable heterogeneity in efficacy and toxicity across human populations $[1,2]$. This heterogeneity can lead to unpredictable life-threatening or even lethal adverse effects in patients who react hypersensitively $[3,4]$. The interindividual variability in drug response cannot satisfactorily be explained by clinical factors such as renal and liver function, patient's age and comorbidity, lifestyle, or co-medication and compliance of the patient. Therefore, molecular factors come into the center of interest.

In the past decades, enormous efforts have been undertaken to predict drug resistance in vitro [5, 6]. The idea was to determine sensitivity or resistance beforehand to be subsequently able to 
choose the clinically most effective treatment for each individual patient. The methods available at that time, however, were not established for clinical routine diagnostics. In the 1990s, attempts were made to test the drug response of cancers by determination of the expression of resistance proteins. However, it was not possible to define consensus recommendations for the standardized detection of resistance proteins expressed in low amounts in tumors with low degrees of drug resistance [7-9]. Hence, this approach was also not realized in clinical routine. Another important reason is that no single mechanism can sufficiently explain resistance to therapy [10]. While the concept of individualized therapy itself traces back to the 1950s [11], the advances in cell and molecular biology have only recently opened new avenues for the characterization of drug-resistant tumors. Still, the transfer of such techniques from the bench to the bed is an unfulfilled requirement. Nevertheless, current progress in molecular biology gives reason to believe that molecular approaches will significantly improve individual tumor therapy.

In the present overview, we focus mainly on our own efforts in this thriving field of research. We searched for novel markers to predict the responsiveness of tumors to chemotherapy and the survival chances of patients at the level of DNA, mRNA, and proteins ( Fig. 1). Promising candidate markers from these analyses were then taken to identify novel compounds derived from natural origin, which specifically target these markers. In a recent survey from the National Cancer Institute (NCI, USA), it was convincingly shown that the majority of cancer drugs brought on the market during the past half century is derived from natural sources or is based on principles of action taken from nature [12, 13]. Therefore, we have concentrated on natural products [1416]. For general overviews in the field of personalized cancer medicine, the reader is also referred to comprehensive reviews in the literature [17-22].

A special feature of our concept is the combination of methods of molecular diagnostics to identify prognostic markers with natural product research to identify inhibitors for these markers. Normally, both areas of research are separated from each other. An integration of both areas in one interdisciplinary approach may open new avenues for the development of novel treatment options for cancer.

\section{Predictive DNA markers}

Classical cytogenetics: Clear cell renal cell carcinoma is a tumor type with a poor prognosis and low responsiveness towards chemotherapy. Less than $50 \%$ of patients can be cured by other therapies such as surgery. To evaluate the prognostic significance of cytogenetic findings in clear cell renal cell carcinoma, the results of classical cytogenetic staining techniques (DAPI-staining and G-banding) and the results of 118 primary RCCs were evaluated in relation to classical indicators of prognosis and overall survival [23]. Losses at the short arm of chromosome 3 (3 p) were most prevalent and included 32 monosomies of chromosomes 3 and 84, structural aberrations involving unbalanced translocations resulting in duplication of sequences at the long arm of chromosome 5 ( $5 \mathrm{q})$. Patients with the gain of band 31 to the end of chromosome 5 ( 5 q31-qter) had a significantly better outcome than those without this aberration $(p=0.001)$. There was no association between the gain of $5 \mathrm{q}$ and any of the well-known variables for prognosis, including low versus high clinical stage and grade of malignancy. Among additional chromosomal aberrations, loss of chromosome $9 / 9 \mathrm{p}$ was associated with distant metastasis at diagnosis $(\mathrm{p}=0.006)$. The data indicate that the gain of 5 q identifies a clinically favorable cytogenetic variant of clear cell renal cell carcinoma and demonstrate the impact of specific chromosome aberrations as additional prognostic indicators in clear cell RCC. The usefulness of cytogenetics for prognosis of a wide variety of hematopoietic and solid cancers has been demonstrated during the past two decades [24-33].

Comparative genomic hybridization (CGH): CGH is an advanced cytogenetic method to analyze unbalanced genomic aberrations, i.e., gains and losses of genetic material (amplifications and deletions). Balanced aberrations (translocations and inversions) cannot be visualized by CGH. In a pilot project, we analyzed whether it is possible to dissect drug-resistant tumor cells from sensitive ones by comparative genomic hybridization. Ten T-cell acute lymphoblastic (T-ALL) CEM cell lines selected for resistance towards methotrexate, doxorubicin, vincristine, or hydroxyurea, respectively, and parental drug-sensitive CCRF-CEM cells were analyzed [34]. Most genomic imbalances were not specific for drug resistance, as they were found in both parental and drug-resistant lines. We were concerned with those imbalances, which were specifically present in drug-resistant, but not in drug-sensitive cells. All methotrexate-resistant cell lines were characterized by an enhancement or an amplification of 5q13. The methotrexate resistance-conferring dihydrofolate reductase (DHFR) gene is located at this locus. Gain of DHFR was verified by PCR analyses. Some but not all methotrexate-resistant cell lines showed enh(14q21qter) and amp(5p13p15.2). These two loci harbor the methylenetetrahydrofolate dehydrogenase (MTHFD1) and 5'methyltetrahdrofolate-homocysteine methyltransferase reductase (MTRR) genes, both of which are involved in folate metabolism. Their gain indicates a role in methotrexate resistance. A loss of $4 \mathrm{q} 35$ was found in two methotrexate-resistant sublines and in the doxorubicin-resistant cells, where the proapoptotic caspase3 gene is located. The thioredoxin (TXN) locus 9q31 was also enhanced in the doxorubicin-resistant cell line. Furthermore, 2p22pter was increased in hydroxyurea-resistant CEM cells. Ribonucleotide reductase polypeptide M2 (RRM2), which confers resistance to hydroxyurea, resides at this locus.

Furthermore, genomic imbalances were investigated in $15 \mathrm{~T}$-cell acute lymphoblastic leukemia cell lines using CGH [35]. In addition, the in vitro response to the cytostatic drug doxorubicin was evaluated by means of a growth inhibition assay. The most frequent genomic imbalance (gain of 6q23) was shared by 9 of the 15 cell lines. This chromosomal locus harbors the C-MYB oncogene. A significant loss of 18q23 was observed in eight lines. Seven of the cell lines were characterized by a loss of the entire short arm of chromosome 9 or parts of it with 9p21 as a minimal band of overlap. This locus contains the tumor suppressor genes INK4A, INK4B, ARF and the MTAP gene. Interestingly, cell lines with a 9p21 deletion exhibited twice the number of gains and 1.6 times the number of losses per line as compared with the cell lines without this deletion. Based on the dose-response curves of the cell lines for doxorubicin, eight doxorubicin-sensitive cell lines had an inhibition concentration $50 \%\left(\mathrm{IC}_{50}\right)<10 \mathrm{nM}$ (CCRF-CEM2, JURKAT, KE-37, MOLT-3, MOLT-4, P12-Ichikawa, PEER, and RPMI8402) and seven doxorubicin-resistant cell lines had an $\mathrm{IC}_{50}$ $>10$ nM (BE-13, CCRF-CEM1, HUT-78, J-Jhan, Karpas-45, MOLT17 , and PF-382). The average number of copy number alterations (CNAs) per cell line was higher in the sensitive than in the resistant group.

Eight cell lines newly established from glioblastoma multiforme were also examined by CGH for their patterns of genomic imbalance [36]. The total number of CNAs varied between 15 and 24 
indicating a distinctly progressed karyotypic evolution. The most frequent CNAs were gains of the entire chromosome 6 or, at least, parts of it, and of $7 \mathrm{p} 22$. Other changes were gains of 3q26qter and the entire chromosome 7 and losses of segments on chromosome $4 \mathrm{q}$ and of the short arm of chromosome 10. Enh(3q21q25), $\operatorname{dim}(4 q 22 q 33)$ and $\operatorname{dim}(4 q t e r), \operatorname{dim}(9 p 21), \operatorname{dim}(13 q 22), \operatorname{enh}(15-$ q14), and enh(18q22q23) were also frequently observed. Using a hierarchical cluster analysis, the specific patterns of genomic imbalance allowed the separation into two main groups indicating different karyotypic evolutions.

As a next step, we applied CGH to clinical biopsies of tumors to determine whether meaningful data can be obtained which are predictive for response to therapy and survival time. We and others applied CGH on oral squamous cell carcinoma [37]. Gain of $11 \mathrm{q} 13$ was involved in advanced stages of malignancy in oral squamous cell carcinoma. In addition, the proportion of patients deceased within one year after diagnosis was higher in the group whose tumors showed an increased 11q13 copy number as compared to the group without this increase. This could point to an association of gain in 11q13 and tumor aggressiveness [38]. Several cancer-related genes reside to this chromosomal locus making the association with tumor aggressiveness and an enhancement of band 13 at the long arm of chromosome 11 reasonable. Among these genes are the oncogenes EMS1, EMSY, FGF3, FGF4, the cell-cycle regulator CCND1 and the TAOS1 gene, which is involved in tumor progression. This locus also harbors the ORAOV1 gene (oral cancer overexpressed gene 1). Patients with tumors characterized by the gain of 3q26-qter plus 5p14-p15 died earlier (i.e., less than 15 months) after excision of the tumor compared to the group without these imbalances [39]. Nineteen of 35 tumors showed a gain of chromosome band 7p12 [239], where the gene for the epidermal growth factor receptor (EGFR) is located. A highly complex but strikingly consistent pattern of other genomic imbalances (average, 32 CNAs per tumor) was associated with the $7 \mathrm{p} 12$ alteration. Average disease-free survival of tumors without a $7 \mathrm{p}$ gain clearly exceeded that of tumors with a gain of 7 p (36.8 vs. 21.3). Relapse occurred in $63 \%$ in the $7 p 12-$ positive vs. $25 \%$ in the negative group. Average disease-free survival of tumors without the $7 \mathrm{p}$ gain clearly exceeded that of tumors with the gain of $7 p$ (36.8 vs. 21.3). Then, genomic imbalances were investigated by hierarchical cluster analysis and clustered image mapping to investigate whether genomic profiles correlate with clinical data. There was indeed a significant relationship: patients suffering from tumors without enh(7p12) lived significantly longer than patients with tumors that harbor $\operatorname{enh}(7 p)(p=0.024)[39,40]$. The data clearly show that several genomic imbalances may affect the clinical outcome in human oral squamous cell carcinoma.

DNA methylation: The genome-wide simultaneous methylation status of $\mathrm{CpG}$ islands in colorectal carcinoma was investigated by means of a microarray-based technique [31]. Amplicons from tumor and control samples were pools of differentially methylated $\mathrm{CpG}$ island fragments hybridized to a panel of approximately $8000 \mathrm{CpG}$ island tags. Data analysis identified $694 \mathrm{CpG}$ island loci hypermethylated in a group of 14 colorectal tumors. The Stanford hierarchical cluster algorithm segregated the tumors into two subgroups, one of which exhibited a high level of concurrent hypermethylation while the other had little or no methylation. This is in agreement with observations of a $\mathrm{CpG}$ island methylation phenotype present in colorectal tumors [42]. The present study demonstrates that this microarray-based tech- nique is useful in classifying tumors according to their methylation profiles.

Single nucleotide polymophisms: An important result of the human genome project is the high DNA variability. Statistically a genetic variation (polymorphism) occurs once in 1200 bases. In most cases, polymorphic gene variants lead to a diminished protein function; in some cases, however, increased activities have been reported [1]. In contrast to somatic mutations, i.e., in cancer, polymorphisms in germ line cells are stable and heritable. Polymorphisms include single nucleotide polymorphisms (SNPs), and length differences in micro- and minisatellites. An SNP represents a single base exchange that may or may not cause an amino acid exchange in the encoded protein. The frequency of SNPs is greater than $1 \%$ in a population and accounts for over $90 \%$ of genetic variation in the human genome. The number of SNPs has been estimated in a range from 1 to 10 million [43-45]. Between 50000 and 250000 SNPs are distributed in and around coding genes [46].

In our research, we focused on SNPs in drug transporter genes. The ATP-binding cassette (ABC) transporter family consists of 49 members. More than 10 of them are implicated in drug resistance to cancer chemotherapy [47-49]. They are important determinants of drug absorption, tissue targeting, and drug elimination. $A B C$ transporters confer drug resistance by lowering the intracellular drug concentrations down to sublethal levels. Cancer cells, which express P-glycoprotein (ABCB1, MDR1) reveal a multidrug resistance phenotype to a broad range of structurally and functionally different drugs, including anthracyclines, anthracenediones, Vinca alkaloids, taxanes, epipodophyllotoxins, and others. P-glycoprotein is also expressed in various normal organs, such as brain vessels, adrenal gland, kidney, liver, and gastrointestinal tract. P-glycoprotein contributes to the blood-brain barrier, translocates hormones, and detoxifies xenobiotics taken up along with nutrients. Although the clinical therapy failure of tumors is multifaceted, its role for drug resistance is evident, and the prognostic significance of P-glycoprotein as an indicator for failure of chemotherapy and poorer outcome has been demonstrated in a number of studies [50-55]. As of yet, 29 polymorphisms have been identified in the $A B C B 1$ gene, with considerable differences in their frequencies among ethnic groups [5659]. Of them, the G2677T/A SNP in exon 21 and the C3435T SNP in exon 26 have been most intensively studied, because they diminish the expression and function of P-glycoprotein $[58,60]$. Whereas the C2677T/A polymorphism causes an A893S/T amino acid substitution, the functional relevance of the C3435T variant is unknown, because this is a silent SNP. It is possible that specific haplotypes of the ABCB1 (MDR1) gene might determine the efficacy and toxicity of drugs. The effect of the G2677T and C3435T SNPs on the pharmacokinetics and pharmacodynamics of drugs is still a matter of controversy, since contrasting results have been provided [61-68]. The expression of P-glycoprotein in normal tissues is thought to play an important role for the pharmacokinetics and pharmacodynamics of many drugs of different drug classes. A definitive answer on the role of $A B C B 1$ SNPs requires further studies.

\section{Predictive mRNA markers}

We have developed a low-density DNA microarray which contains 38 genes of the ATP-binding cassette (ABC) transporter gene family [69]. This tool has been validated with three different multidrug-resistant sublines (CEM/ADR5000, HL60/AR, and MCF7/ CH1000) known to overexpress either the ABCB1 (MDR1), ABCC1 


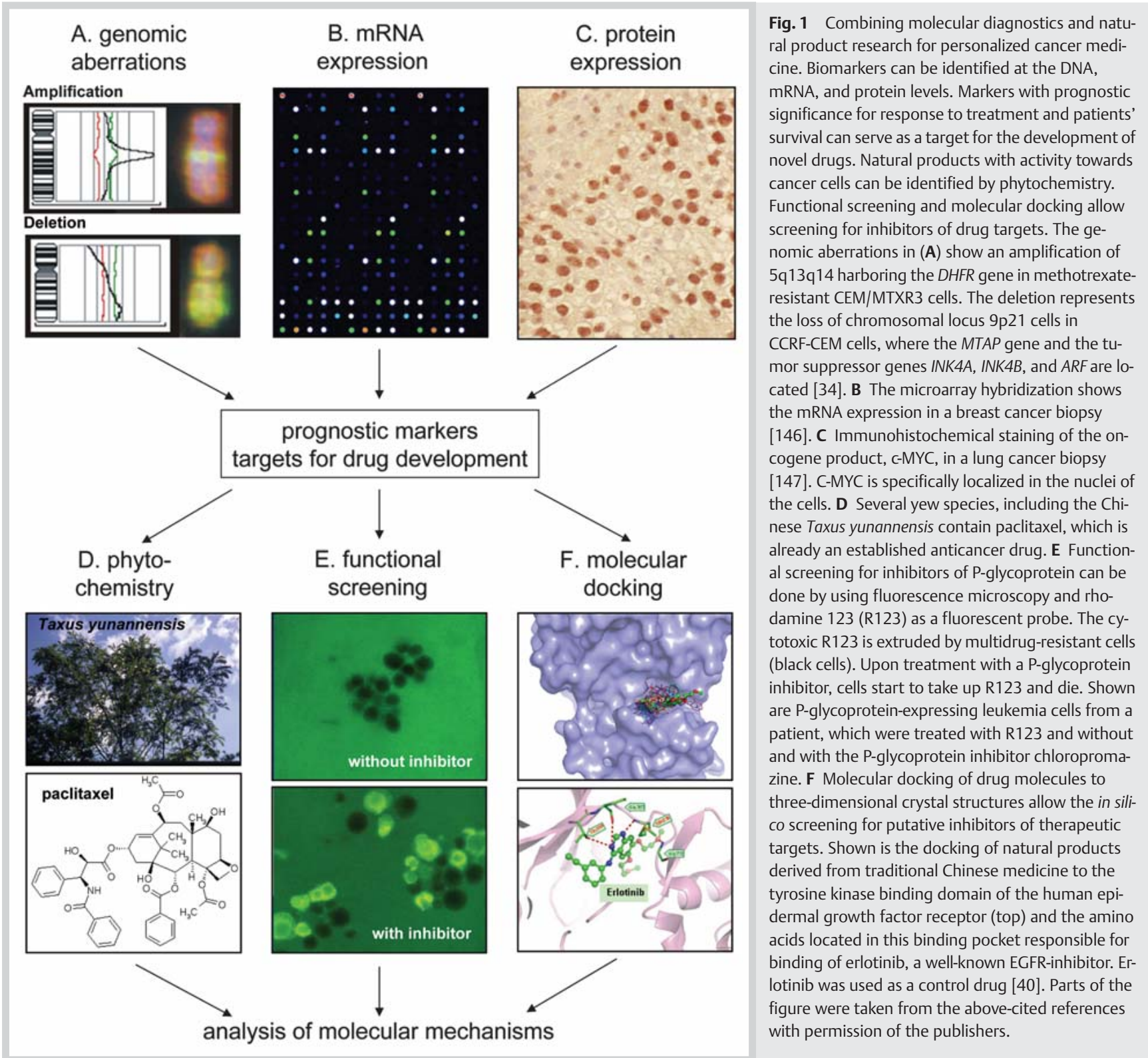

(MRP1), or ABCG2 (MXR, BCRP) genes. When compared with their drug-sensitive parental lines, we observed not only the overexpression of these genes in the multidrug-resistant cell lines but also of other $A B C$ transporter genes, pointing to their possible role in multidrug resistance. These results were corroborated by quantitative real-time reverse transcription-PCR [69].

As a next step, we applied this microarray to detect drug resistance in clinical samples. We identified four new ABC transporters, which were overexpressed in many samples of patients with acute myeloid leukemia (AML) compared with healthy bone marrow: $A B C A 2, A B C A 3, A B C B 2$, and $A B C C 10$ [70]. The overexpression of these four genes was verified by real-time PCR in 42 samples from children with AML and 18 samples of healthy bone marrow. The median expression of $A B C A 3$ was three times higher in 21 patients who had failed to achieve remission after the first course of chemotherapy than in a well-matched group of 21 patients who had achieved remission at this stage $(p=0.023)$. Incubation of cell lines with a number of different cytostatic drugs induced an upregulation of $A B C A 3$. Downregulation of $A B C A 3$ by small interfer- ing RNA sensitized cells to doxorubicin. These results show that $A B C A 2, A B C A 3, A B C B 2$, and $A B C C 10$ might play a role for AML. ABCA3 is the most likely transporter to cause drug resistance. Furthermore, we observed a consistent overexpression of $A B C A 2$ / $A B C A 3$ in clinical samples of T-cell acute lymphoblastic leukemia (T-ALL) [71]. Therefore, we analyzed the association of these two genes with drug resistance. Treatment of CCRF-CEM and Jurkat cells with methotrexate, vinblastine, or doxorubicin led to an induction of $A B C A 3$ expression, whereas a significant increase of $A B C A 2$ expression was only observed in Jurkat cells. To study the causal relationship of $A B C A 2 / A 3$ overexpression with drug resistance, we applied RNA interference (RNAi) technology. RNAi specific for $A B C A 2$ or $A B C A 3$ led to a partial decrease of expression in these two $A B C$ transporters. Upon cotreatment of RNAi for $A B C A 2$ with methotrexate and vinblastine, a partial decrease of $A B C A 2$ expression as well as a simultaneous increase of $A B C A 3$ expression was observed. Vice versa, $A B C A 3$ RNAi plus drugs decreased $A B C A 3$ and increased $A B C A 2$ expression. This indicates that downregulation of one $A B C$ transporter was compensated by 
the upregulation of the other. Application of RNAi for both $A B C A 2$ and $A B C A 3$ resulted in a more efficient reduction of the expression of both transporters. As a consequence, a significant sensitization of cells to cytostatic drugs was achieved. In conclusion, $A B$ $C A 2$ and $A B C A 3$ are expressed in many T-ALL and contribute to drug resistance.

\section{Predictive protein markers}

So far, our data obtained from CGH and DNA methylation analysis indicate that no single mechanism can explain the resistance to chemotherapy. The multifactorial nature of drug resistance implies that the analysis of comprising expression profiles may predict drug resistance with higher accuracy than single gene or protein expression studies. Therefore, 40 cellular parameters (drug resistance proteins, proliferative, apoptotic, and angiogenic factors, products of proto-oncogenes, and suppressor genes) were evaluated mainly by immunohistochemistry in specimens of primary non-small cell lung carcinoma (NSCLC) of 94 patients and compared with the response of the tumors to doxorubicin in vitro [72]. The protein expression profile of NSCLC was determined by hierarchical cluster analysis and clustered image mapping. The cluster analysis revealed three different resistance profiles. The frequency of each profile was different. The resistance proteins P-glycoprotein (MDR1, ABCB1), thymidylate synthetase, glutathione-S-transferase- $\pi$, metallothionein, $O^{6}$-methylguanineDNA-methyltransferase and major vault protein/lung resistancerelated protein were most frequently upregulated in one of the three clusters, while microvessel density, the angiogenic factor vascular endothelial growth factor and its receptor FLT1, and ECGF1 as well were downregulated. In addition, the proliferative factors proliferating cell nuclear antigen and cyclin A were reduced compared to the sensitive NSCLC. In this resistance profile, FOS was upregulated and NM23 downregulated. In the second profile, only three resistance proteins were increased (glutathione-S-transferase- $\pi, O^{6}$-methylguanine-DNA methyltransferase, major vault protein/lung resistance-related protein). The angiogenic factors were reduced. In the third profile, only five of the resistance factors were increased (P-glycoprotein, thymidylate synthetase, glutathione- $S$-transferase- $\pi, \quad O^{6}$-methylguanineDNA-methyltransferase, major vault protein/lung resistance-related protein).

In a second analysis, we analyzed the expression of resistance-related proteins for survival times of patients. NSCLC is usually associated with a poor survival prognosis [73]. Some patients survive their disease, and the underlying molecular mechanisms are still poorly understood. Therefore, we have evaluated the expression of 21 gene products (oncogene and tumor suppressor products and proliferative, apoptotic, and angiogenic factors) in paraffin-embedded primary NSCLCs from 216 patients and correlated the data with the survival times of the patients (survival of more or less than five years). The protein expression of FOS, P53, RAS, ERBB1, JUN, PCNA, cyclin A, FAS/CD95, and HIF-1 $\beta$ revealed a correlation to survival by means of the $X^{2}$ test. In a second step, these nine parameters were further analyzed by hierarchical cluster analyses of all patients, of stage III patients, and of patients with squamous cell lung carcinomas. We identified clusters with significantly more long-term survivors. The expression of FOS, JUN, ERBB1, and cyclin A or PCNA were decreased in carcinomas of patients with long-term survival. The expression profile of these factors predicts a significantly better long-term outcome of NSCLC patients. This may have implications for the development of individualized therapy options in the future.
Survival time of patients is mostly influenced by metastasis. Therefore, we were also interested to investigate the role of these proteins for metastasis and to evaluate whether different protein expression patterns exist in primary squamous cell lung carcinomas of patients with and without lymph node involvement. Formalin-fixed, paraffin-embedded specimens from 130 patients with squamous cell lung carcinomas were analyzed by immunohistochemistry [74]. In a first step, proteins were selected which showed a relationship to lymph node involvement. The expression of JUN, ERBB2, MYC, cyclin D, PCNA, bFGF, VEGF and Hsp70 proteins revealed a positive correlation to lymph node involvement. In contrast, caspase-3, Fas ligand, Fas/CD95, and PAI showed an inverse correlation to lymph node involvement. In a second step, these parameters were further analyzed by hierarchical cluster analyses. The resulting clusters were correlated to patients with or without lymph node involvement. The data show that different protein expression patterns exist between primary squamous cell lung carcinomas with and without lymph node involvement and within carcinomas with lymph node involvement. The data suggest that various metastasis profiles exist. This has also been shown for other tumor types by other authors [75-83].

\section{Molecular Targeted Therapy with Natural Products} $\nabla$

\section{A chemical "treasure box" from medicinal plants}

Given the fact that a considerable portion of all drugs used nowadays in oncology as well as in general pharmacology are from natural origin [12,13], natural products represent a valuable source for drug development. Surprisingly, this potential is frequently underestimated in pharmacology, biology, and medicine. In Europe, medicinal herbs gradually lost importance in the course of chemistry's progress in industrialized countries during the 20th century. From the perspective of the pharmaceutical industry, chemical compounds from natural origin may pose more problems concerning intellectual property and patenting issues. Furthermore, plant extracts can hardly be subjected to highthroughput screening technologies. For pharmaceutical chemists, it might be more attractive to fiddle about huge chemical libraries of synthetic compounds obtained by combinatorial chemistry than to isolate compounds from plants, which can be painful and time-consuming. This might at least in part explain the decline of natural products in drug development during the 20th century. Fortunately, the potential of natural products for chemotherapy seems to be rediscovered very recently, and the current thriving revival of phytotherapy is followed by an increasing scientific interest in bioactive compounds as lead drugs for semisynthetic modification.

Our own interest to identify novel cytotoxic compounds with activity against tumor cells derived from medicinal plants used in traditional Chinese medicine (TCM) was raised in the 1990s [84]. The rationale behind this approach is that TCM looks back on a tradition of more than 5000 years. Hence, it can be expected that many ineffective medicinal herbs have vanished over the centuries. Indeed, a number of clinical studies were conducted on TCM providing convincing evidence to gain credibility and reputation outside China. As recently reviewed, clinical trials with TCM remedies focus on three major fields in cancer research: (i) improvement of poor treatment response rates towards standard chemo- and radiotherapy, (ii) reduction of severe 
adverse effects of standard cancer therapy, and (iii) unwanted interactions of standard therapy with herbal medicines [85].

Apart from the approved drugs artemisinin and its semisynthetic derivative artesunate $[86,87]$, we have analyzed cellular and molecular mechanisms of several other chemically characterized natural products derived from TCM. Among them were known compounds with still insufficiently defined modes of action, which were investigated by us using molecular biological and pharmacogenomic approaches, i.e., arsenic trioxide, ascaridol, berberine, cantharidin, cephalotaxine, curcumin, homoharringtonine, luteolin, isoscopoletin, scopoletin, vitexin, isovitexin, and others [88-109]. Furthermore, several novel bioactive compounds were described and analyzed in the course of our investigations, i.e., tetracentronsine $\mathrm{A}$, tetracentronsides $\mathrm{A}, \mathrm{B}$ and $\mathrm{C}$, the two novel $\alpha$-tetralone derivatives, berchemiasides $A$ and $B$, as well as the novel flavonoid quercetin-3-O-(2-acetyl- $\alpha$-L-arabinofuranoside) [110-112]. Artemisinin also reveals profound antimalarial activity [14]. During the past years, several derivatives (artesunate, artemether, arteether, artelinate) have been synthesized to improve the antimalarial activity.

Furthermore, we started the analysis of antiviral effects of natural products. We were the first to demonstrate that artesunate inhibits NF-KB activity, leading to the inhibition of viral replication. NF-KB is involved in the transcriptional regulation of immediate early, early, and late proteins of human cytomegalovirus (HCMV) necessary for viral replication [113]. Artesunate also acts against cytomegaloviruses in vivo [114]. The antiviral activity of artesunate is not limited to HCMV. We showed that herpes simplex virus 1 , hepatitis $B$ and $C$ viruses and others are also efficiently inhibited by artemisinin and artesunate $[115,116]$.

Summarizing the results of our investigations in search of molecular markers, it turned out that patient survival and response to chemotherapy is multifactorial and that no single factor sufficiently explains treatment failure and death. We conclude that resistance markers may also be valuable targets for strategies to develop targeted therapies for individual cancer patients. The idea is to identify small molecules, which inhibit proteins that are essential for therapy response and worse prognosis. The focus of our own research is on small molecules from natural origin. We have selected three targets to prove the validity of this concept: (i) the chromosomal locus 9p21 harbors several genes, including MTAP, INK4A, INK4B, and ARF. MTAP offers the opportunity for a chemoselective treatment which affects tumor cells with 9p21 deletion but spares normal tissues; (ii) P-glycoprotein is an efflux transporter that extrudes many anticancer drugs out of tumor cells rendering them resistant to chemotherapy. We have searched for compounds that are not recognized by P-glycoprotein and which, hence, kill P-glycoprotein-expressing multidrug-resistant tumor cells with a similar efficacy than P-glycoprotein-negative drug-sensitive cells. Alternatively, the inhibition of this drug transporter by small molecules may overcome multidrug resistance; (iii) EGFR represents an important signal transducing molecule regulating tumor growth, apoptosis, differentiation and other key processes. The recognition of its value as a target for novel drugs resulted in the development of therapeutic antibodies and small molecules. However, tumor cells can also exert resistance to these novel therapeutics and novel EGFR inhibitors are required.

\section{Chemoselective treatment of tumor cells with}

\section{9p21 deletion by L-alanosine}

Unfortunately, most established anticancer drugs not only kill tumor cells but also affect normal tissues [117]. It would, thus, be desirable to have treatment targets which allow the distinction between normal and cancerous tissue.

A deletion of the short arm of chromosome 9 at band 21 (9p21) is a frequent chromosomal aberration in many tumor types including acute lymphoblastic leukemia $[118,119]$. This locus harbors the tumor suppressor genes p16 ${ }^{\mathrm{INK} 4 \mathrm{~A}}$, its alternative splice product $\mathrm{p} 14^{\mathrm{ARF}}$, and $\mathrm{p} 15^{\mathrm{INK} 4 \mathrm{~B}}$. Their gene products regulate the progression from G1 to $S$ phase of the cell cycle via the RB1 or p53 pathways [120]. In addition, the methylthioadenosine phosphorylase (MTAP) gene is also localized at this chromosomal region and $16^{\text {INK4A }}$ and MTAP genes are frequently codeleted in tumors [121]. MTAP converts methylthioadenosine into adenine and 5methylthioribose 1-phosphate by phosphorolysis. Adenosine is used to recruit adenine nucleotide pools for DNA synthesis. Methylthioadenosine can, therefore, serve as an alternative purine source, if the de novo purine biosynthesis is inhibited by antimetabolites, i.e., methotrexate [122]. Tumor cells with a deletion of the MTAP gene at chromosome 9p21 cannot use this salvage pathway and die upon methotrexate challenge. As all normal tissues have MTAP activity [122], they do not die at methotrexate concentrations lethal for MTAP-deficient cancer cells. The MTAP salvage pathway may, thus, offer a unique opportunity for a selective tumor therapy which spares normal tissues. This treatment advantage may, however, vanish in MTAP-deficient cells, which developed resistance towards MTX, i.e., by amplification of the dihydrofolate reductase gene.

Therefore, we analyzed the role of MTAP for chemoselectivity of the antimetabolites trimetrexate and L-alanosine and whether cross-resistance to methotrexate hampers their effectiveness $[123,124]$. Trimextrexate is a derivative of the established anticancer drug methotrexate. L-Alanosine is an amino acid analogue and antibiotic derived from the bacterium Streptomyces alanosinicus. The analyses were performed with CCRF-CEM cells in which the 9p21 deletion was found by CGH and fluorescence in situ hybridization. T-cell acute lymphoblastic leukemia (T-ALL) cells (CCRF-CEM) were transfected with an MTAP expression vector. A green fluorescent protein (GFP) plasmid was co-transfected to monitor the transfection efficacy by flow cytometry. The response of MTAP-transfected cells to the antimetabolites methotrexate, trimetrexate, and L-alanosine was decreased compared to mock control transfectants using growth inhibition assays. The activity of doxorubicin which is not involved in DNA biosynthesis was not changed in MTAP transfectants. As the p16 ${ }^{\mathrm{INK} 4 \mathrm{~A}}$ tumor suppressor gene resides also at 9p21, we transfected CCRF-CEM cells with a $\mathrm{p} 16^{\mathrm{INK} 4 \mathrm{~A}}$ expression vector. These transfectant cells were more resistant to all four drugs indicating that p $16^{\text {INK4A }}$ did not specifically affect antimetabolites. The chemoselective effect of antimetabolites in MTAP-deleted tumor cells may, however, be compensated by the development of drug resistance. To prove this possibility, we analyzed a methotrexate-resistant subline, CEM/MTX1500LV, in which the methotrexate resistance-conferring dihydrofolate reductase (DHFR) gene was amplified. While trimetrexate exhibited considerable cross-resistance in CEM/MTX1500LV cells, L-alanosine did not. Thus, L-alanosine could exhibit chemoselectivity in 9p21/MTAP-deleted cells, even if DHFR amplification occurs. We conclude that L-alanosine may be more suitable than methotrexate or trimetrexate for MTAP-mediated chemoselective treatment of T-ALL. Pre-ther- 
apeutic detection of 9p21 and MTAP deletion may be helpful in developing a predictive molecular chemosensitivity test for T-ALL.

\section{Natural products that bypass or modulate}

P-glycoprotein-mediated multidrug resistance

Non-cross-resistant natural products: In a recent investigation, we analyzed the cross-resistance profile of clinical samples of 59 tumors of different origins and 38 lung tumors in vitro [125]. Cytostatic drugs from different classes were used (anthracyclines, antibiotics, Vinca alkaloids, epipodophyllotoxins, antimetabolites, and alkylating agents). Tumors exert broad resistance profiles. Tumors resistant to one drug also tend to be resistant to other drugs, while sensitive tumors reveal sensitivity towards many drugs. Expression of P-glycoprotein and the proliferative activity of tumors were identified as underlying mechanisms of broad spectrum resistance.

As a second step, the cross-resistance profiles were analyzed in sensitive and resistant cell lines from different tumor types to study underlying mechanisms. In an effort to find new treatment possibilities, novel cytotoxic compounds with activity against otherwise drug-resistant tumor cells were investigated [125]. We used the CEM/ADR5000 leukemia cell line overexpressing Pglycoprotein/MDR1 and its parental cell line, CCRF-CEM to investigate cross-resistance profiles. CEM/ADR5000 cells were more than 1000 -fold resistant to the selecting agent, doxorubicin. They were also highly cross-resistant to the anthracycline epirubicin (484-fold) but less cross-resistant to idarubicin (6.9-fold). We also tested the anthracycline metabolites doxorubicinol, epirubicinol, and idarubicinol, which revealed cross-resistance to a lesser degree than the non-metabolized parental drugs (range from 1.6- to 382-fold). Cross-resistance to the Vinca alkaloids vincristine, vinblastine, vindesine, and vinorelbine was in a range of 14- to 613-fold and to the taxanes paclitaxel and docetaxel in a range of 200- to 438-fold. The degrees of resistance to the epipodophyllotoxines etoposide and etoposide phosphate were lower (18- and 11-fold, respectively). In an effort to identify novel compounds with activity against otherwise drug-resistant tumor cells, we analyzed natural products derived from medicinal plants used in traditional Chinese medicine (TCM) in CCRF-CEM and CEM/ADR5000 cells. Interestingly the multidrug-resistant cells revealed either low degree of cross-resistance (cephalotaxine, berberine, homoharringtonine, maesopsin), no clear crossresistance (E)-3-(4-hydroxyphenyl)-[2-(4-hydroxyphenyl)-ethyl]-prop-2-enamide, $N$-p-coumaryl tyramine, maslinic acid) or even enhanced sensitivity towards the natural products from TCM [cantharidin, tetracentronside, 3-(2-hydroxyethyl)- $1 \mathrm{H}$-indole-5-O- $\beta$-D-glucopyranoside, kaempferol, artesunate].

In order to gain a systematic approach in identifying natural products from TCM with inhibitory activity against multidrug-resistant tumor cells, we compiled 531 cytotoxic natural products and derivatives thereof in a database [126]. These compounds were tested in the drug screening program of $\mathrm{NCl}$ (www.dtp.nci. nih.gov). In combination with microarray data, the generation of hypotheses regarding their modes of action is a starting point for further mechanistic studies. We correlated the $\mathrm{IC}_{50}$ values of the $60 \mathrm{NCl}$ tumor cell lines for these 531 natural products with the accumulation data for rhodamine 123 (R123) as a functional assay for P-glycoprotein and with the cell doubling times as a parameter of proliferation. While the $\mathrm{IC}_{50}$ values for only $18 \mathrm{com}$ pounds correlated with R123 accumulation (3\%), 162 natural products were significantly associated with the cell doubling times of the cell lines (31\%), indicating that natural products might be a rich source for novel drug candidates with activity to bypass P-glycoprotein- and proliferation-associated drug resistance. We will systematically exploit the chances to develop novel cancer drugs from TCM with improved features.

Modulators of P-glycoprotein function: Another concept was the blockage of P-glycoprotein by specific inhibitors. Despite huge efforts in academia and industry, no P-glycoprotein inhibitor has clinically showed satisfying results and reached the pharmaceutical market yet $[127,128]$. Most of these resistance-modifying agents (RMA) are too toxic at the required doses. Therefore, the development of novel RMAs to overcome MDR represents a major challenge to modern cancer chemotherapy. In this context, we analyzed natural products for their ability to inhibit P-glycoprotein function.

The antimycobacterial quinolones 1-methyl-2-undecyl-4-quinolone, dihydroevocarpine and evocarpine as well as the indoloquinazoline alkaloids rutaecarpine and evodiamine - all from the Chinese medicinal herb Evodia rutaecarpa - were tested in two in vitro assays, for cytotoxicity and interaction with P-glycoprotein. Cytotoxicity was measured in a cell proliferation assay against sensitive CCRF-CEM and multidrug-resistant CEM/ ADR5000 cells. An assay monitoring the P-glycoprotein-dependent accumulation of the dye calcein in porcine brain capillary endothelial cells (PBCECs) was used to study interactions of the test substances with this efflux pump. Rutaecarpine and evodiamine showed quite a high toxicity with $\mathrm{IC}_{50}$ values from 2.64 to $4.53 \mu \mathrm{M}$ and were weak modulators of P-glycoprotein activity. The degrees of resistance in CEM/ADR5000 towards the saturated quinolones 1-methyl-2-undecyl-4-quinolone and dihydroevocarpine were between 3 and 4 . In the calcein assay, these two quinolones were shown to be modulators of P-glycoprotein activity. Evocarpine, on the other side, is not transported by P-glycoprotein, and showed only slight toxicity at the highest test concentration of $30 \mu \mathrm{M}$ [129]. Furthermore, four antimycobacterial geranylated furocoumarins, from the fruits of Tetradium daniellii (Rutaceae) showed considerable cell proliferation inhibition with $\mathrm{IC}_{50}$ values ranging from 1.72 to $11.02 \mu \mathrm{M}$ against CCRF-CEM and 2.09 to $13.56 \mu \mathrm{M}$ against CEM/ADR5000, respectively. The calcein assay to monitor P-glycoprotein function showed that all four compounds are modulators of P-glycoprotein [130].

In another project, we described the effect of oxalyl-bis $(N$-phenyl)hydroxamic acid (OBPHA) and copper $\mathrm{N}$-(2-hydroxyacetophenone)glycinate (CuNG) on multidrug-resistant P-glycoprotein-expressing CEM/ADR5000 T-cell acute lymphoblastic leukemia cells [131]. CuNG, a known depleting agent for glutathione (GSH) and inhibitor of glutathione S-transferase (GST) and multidrug resistance-related protein 1 (MRP1), also inhibited P-glycoprotein-mediated doxorubicin accumulation and retention. The resistance-modifying effects of OBPHA were stronger than that of CuNG. Both novel RMAs overcame drug resistance more efficiently than verapamil, a well-known P-glycoprotein inhibitor. OBPHA and CuNG exposure resulted in an increased doxorubicin accumulation after $1-3 \mathrm{~h}$ incubation by downregulation of P-glycoprotein expression after $24 \mathrm{~h}$ incubation. This is a clue that different mechanisms may contribute to modulation of P-glycoprotein-mediated drug resistance by these compounds.

We investigated the effect of CuNG on reactive oxygen species (ROS) generation and antioxidant enzymes in normal and doxorubicin-resistant Ehrlich ascites carcinoma (EAC/Dox)-bearing Swiss albino mice [132]. The effect of CuNG has been studied on ROS generation, multidrug resistance-associated protein1 
(MRP1) expression and on activities of superoxide dismutase (SOD), catalase (CAT) and glutathione peroxidase (GPX). CuNG increased ROS generation and reduced MRP1 expression in EAC/ Dox cells while only temporarily depleted glutathione (GSH) within $2 \mathrm{~h}$ in heart, kidney, liver and lung of EAC/Dox-bearing mice, which were restored within $24 \mathrm{~h}$. The level of liver copper was observed to be inversely proportional to the level of GSH. Moreover, CuNG modulated SOD, CAT and GPx in different organs and thereby reduced oxidative stress. Hence, nontoxic doses of CuNG may be utilized to reduce MRP1 expression and thus sensitize EAC/Dox cells to standard chemotherapy. Moreover, CuNG modulated SOD, CAT and GPX activities to reduce oxidative stress in some vital organs of EAC/Dox-bearing mice. CuNG treatment also helped to recover liver and renal function in EAC/Doxbearing mice.

Furthermore, we have determined the efficacy of CuNG in overcoming multidrug-resistant cancer using drug-resistant murine and human cancer cell lines [133]. The action of CuNG following single $i . m$. administration ( $5 \mathrm{mg} / \mathrm{kg}$ body weight) was tested in vivo on doxorubicin-resistant Ehrlich ascites carcinoma (EAC/ Dox)-bearing mice and doxorubicin-resistant sarcoma 180-bearing mice. Tumor size, ascitic load, and survival rates were monitored at regular intervals. Apoptosis of cancer cells was determined by cell cycle analysis, confocal microscopy, annexin $\mathrm{V}$ binding, and terminal deoxynucleotidyl transferase-mediated dUTP nick end labeling assay ex vivo. IFN- $\gamma$ and tumor necrosis factor- $\alpha$ were assayed in the culture supernatants of in vivo and in vitro CuNG-treated splenic mononuclear cells from EAC/Doxbearing mice and their apoptogenic effect was determined. Sources of IFN- $\gamma$ and changes in the number of $\mathrm{T}$ regulatory marker-bearing cells in the tumor site following CuNG treatment were investigated by flow cytometry. Supernatants of in vitro CuNG-treated cultures of peripheral blood mononuclear cells from different drug-insensitive cancer patients were tested for presence of the apoptogenic cytokine IFN- $\gamma$ and its involvement in induction of apoptosis of doxorubicin-resistant CEM/ ADR5000 cells. CuNG treatment could resolve drug-resistant cancers through induction of apoptogenic cytokines, such as IFN- $\gamma$ and/or tumor necrosis factor- $\alpha$, from splenic mononuclear cells or patient peripheral blood mononuclear cells and reduced the number of T regulatory marker-bearing cells while increasing infiltration of IFN- $\gamma$-producing $\mathrm{T}$ cells in the ascetic tumor site. Our results show the potential usefulness of CuNG in immunotherapy of drug-resistant cancers irrespective of multidrug resistance phenotype.

Besides P-glycoprotein, other drug transporters have also been described in recent years to confer drug resistance. Among them is the breast cancer resistance protein (BCRP, ABCG2). We have focused on this protein in the context of the highly active antiretroviral therapy (HAART), whose safety and effectiveness is frequently challenged by viral resistance to antiretrovirals and the frequent occurrence of drug interactions which may limit the access of these drugs to the target sites. In particular, drug distribution and elimination may be modified by BCRP. Therefore, we investigated the influence of all important anti-HIV drugs on BCRP activity in vitro in one assay to allow unrestricted comparison of the results [134]. BCRP inhibition was assessed by an increase in pheophorbide A accumulation in expressing MDCKII cells and compared with the corresponding parental cell line MDCKII lacking human BCRP. According to the $\mathrm{IC}_{50}$ estimation, the rank order for BCRP inhibition was lopinavir $>$ nelfinavir $>$ delavirdine $>$ efavirenz $>$ saquinavir $>$ atazanavir $>$ amprenavir $>$ abacavir. Where- as nevirapine and zidovudine exerted weak inhibition, the inhibitory potency for ritonavir and tipranavir could not be estimated due to their low solubility and all other tested compounds (indinavir, didanosine, emtricitabine, lamivudine, stavudine, tenofovir and zalcitabine) were devoid of an effect. This study demonstrated a significant inhibition of BCRP by many anti-HIV drugs. This suggests that inhibition of BCRP might contribute to drugdrug interactions observed during HAART in vivo and possibly also the superior effectiveness of combination antiretroviral therapy.

\section{Natural products that inhibit the epidermal growth factor receptor}

The epidermal growth factor receptor (EGFR) has an extraordinary relevance in tumor biology. In our CGH analyses with oral squamous cell carcinoma, the amplification of the locus 7p12 also points in this direction [39]. A number of novel treatment options for tumors overexpressing EGFR have been launched to the market in recent years, e.g., therapeutic antibodies and small molecules such as gefitinib and erlotinib. These two compounds compete with ATP for binding to the ATP-binding domain of EGFR and, thereby, kill cancer cells. Despite considerable success with EGFR inhibitors, resistance against these new treatment modalities can also occur [135] and novel EGFR tyrosine kinase inhibitors are urgently required.

Using the above-described database with 531 compounds derived from TCM [126]; 35 candidate compounds were identified by correlation analyses of their $\mathrm{IC}_{50}$ values and the microarraybased mRNA expression values of the EGFR gene in 60 cell lines of the NCI [40]. Among the 35 natural products, two have already been reported to be associated with EGFR function [136]. Then, molecular docking studies (or protein-ligand interaction studies) were carried out with these 35 compounds using the crystal structure of the EGFR tyrosine kinase domain as the docking template. As a control, two crystal structures of EFGR tyrosine-kinase domain with inhibitors (erlotinib and lapatinib, respectively) bound in the ATP-binding site were taken from the Protein Data Bank (www.rcsb.org). Visual inspection of erlotinib control docking studies showed that the predicted erlotinib binding site and its orientation in binding site agreed very well as observed in the crystal structure. The predicted $\mathrm{K}_{\mathrm{i}}\left(\mathrm{pK}_{\mathrm{i}}\right)$ values in our approach also agreed well with the reported values in the literature for erlotinib $\left(K_{i}=0.7 \pm 0.1 n M\right)$ and gefitinib $\left(K_{i}=0.4 \pm 0.1 n M\right)$ [137].

The 35 selected TCM compounds were individually docked into the crystal structure of EGFR tyrosine-kinase domain (EGFR-TK) for the appropriate conformational search. Eighteen out of 35 natural products were docked in the erlotinib binding site with docked energy values in the range of -6.6 to $-10.2 \mathrm{kcal} / \mathrm{mol}$. Among them, neo-oxyberberine, dicentrine, piceatannol and organol scarlet exhibit similar binding features to that of erlotinib in the tyrosine-kinase active site of EGFR [40].

Binding site analysis showed that interaction of dicentrine, organol scarlet and erlotinib with residues Thr766 and Met769 was a conserved feature. Thr766 and Met769 formed a hydrogen bond with the quinazoline nitrogen atom of erlotinib, while they were involved in hydrogen bond formation with the benzodioxoloquinoline oxygen atom of dicentrine. In the case of organol scarlet, Thr766 and Met769 formed a hydrogen bond with the diazenyl nitrogen atom of organol scarlet that is not a part of any cyclic system as found in erlotinib [40]. Further investigations are underway to analyze these findings in more detail. 


\section{Conclusions and Perspectives}

\section{$\nabla$}

Our data indicate that a great diversity of molecular mechanisms is operative in clinical drug resistance. We showed that different resistant profiles exist within tumors of homogeneous histology. Thus, it is possible to identify novel subgroups of otherwise homogeneous tumor groups. These results are in accordance with a large body of evidence in the literature [138-144]. The systematic investigation of combinations of cellular factors in cancer clearly yields improved predictive information. Recently developed technologies for genome-, transcriptome- or proteomewide analyses facilitates the simultaneous analyses of thousands of genes or proteins in a single experiment, raising expectations that it will revolutionize cancer diagnosis.

On the other hand, the results of our group as well as of other authors [145] indicate that a minimal set of about 10 to 50 factors may be sufficient and may bring more robust results than sets of thousands of factors. Therefore, it is reasonable to focus on a few relevant prognostic factors which may serve as drug targets to treat individual patients exhibiting these specific poor prognostic factors. We consider these results as one step further to the ultimate goal of prediction of drug response of each individual patient. We have exemplarily done this for three target proteins, i.e., MTAP, P-glycoprotein and EGFR and showed the principal feasibility of this concept.

In the long run, it has to be seen whether genomics and proteomics along with other "-omic" technologies will provide real hope or just another hype. It has to be taken cautiously, bearing in mind that the response to chemotherapy depends not only on intracellular, e.g., molecular and biological factors, but also on extracellular factors. The relevance of pharmacokinetics and dynamics must not be underestimated.

Generally, our knowledge on cancer biology and molecular factors with prognostic significance has exponentially grown over the past two decades delivering a wide array of proteins that may serve as target structures for drug development. This will for sure lead to a tremendous increase in novel compounds to be tested in the years to come, and small molecules will be a major player in this scenario.

Given the fact that a considerable portion of all drugs used nowadays is from natural origin, natural products represent a valuable source for drug development. Chemical compounds developed over millions of years during evolution bear a tremendous potential as novel drugs. The hope is that this potential will be utilized for the sake of the cancer patients.

We will face a shift from the established, rather unspecific and toxic anticancer drugs to new generations of targeted drugs with improved pharmacological features concerning tumor specificity and toxicity. At the moment it cannot be foreseen whether cancer patients will routinely be curable. Rather, cancer might turn from a life-threatening into a chronic disease, which needs life-long therapy. This raises concerns, and one might ask "who should pay?" The only way to reduce costs is to avoid overtreatment of patients. Personalized medicine will provide sophisticated diagnostic tools to adjust the right treatment for the right patient. As a consequence, it is to be hoped that treatment failure and unwanted side effects will more and more disappear and treatment efficacy will raise improving quality of life.

\section{References}

1 Evans WE, Relling MV. Pharmacogenomics: translating functional genomics into rational therapeutics. Science 1999; 286: 487-491

2 Fagerlund TH, Braaten 0 . No pain relief from codeine? An introduction to pharmacogenomics. Acta Anaesthesiol Scand 2001; 45: 140-149

3 Rothenberg ML, Meropol NJ, Poplin EA, van Cutsem E, Wadler S. Mortality associated with irinotecan plus bolus fluorouracil/leucovorin: summary findings of an independent panel. J Clin Oncol 2001; 19: 38013807

4 Sargent DJ, Niedzwiecki D, O'Connell MJ, Schilsky RL. Recommendation for caution with irinotecan, fluorouracil, and leucovorin for colorectal cancer. N Engl J Med 2001; 345: 144-145

5 Salmon SE, Hamburger AW, Soehnlein B, Durie BG, Alberts DS, Moon TE. Quantitation of differential sensitivity of human-tumor stem cells to anticancer drugs. N Engl J Med 1978; 298: 1321-1327

6 Volm M, Drings P, Mattern J, Sonka J, Vogt-Moykopf I, Wayss K. Prognostic significance of DNA patterns and resistance-predictive tests in nonsmall cell lung carcinoma. Cancer 1985; 56: 1396-1403

7 Beck WT, Grogan TM, Willmann CL, Cordon-Cardo C, Parham DM, Kuttesch JF, Andreeff M, Bates SE, Berard CW, Boyett JM, Brophy NA, Broxterman HJ, Chan HS, Dalton WS, Dietel M, Fojo AT, Gascoyne RD, Head D, Houghton PJ, Srivastava DK, Lehnert M, Leith CP, Paietta E, Pavelic ZP, Weinstein $R$. Methods to detect P-glycoprotein-associated multidrug resistance in patients' tumors: consensus recommendations. Cancer Res 1996; 56: 3010-3020

8 Beck WT, Grogan TM. Methods to detect P-glycoprotein and implications for other drug resistance-associated proteins. Leukemia 1997; 11: 1107-1109

9 Efferth T. Testing for tumor drug resistance in the age of molecular medicine. A contribution to the debate round-table on phenotypic and genotypic analyses of multidrug resistance (MDR) in clinical hospital practice. Leukemia 1997; 13: 1627-1629

10 Volm M, Mattern J. Resistance mechanisms and their regulation in lung cancer. Crit Rev Oncog 1996; 7: 227-244

11 Cortazar P, Johnson BE. Review of the efficacy of individualized chemotherapy selected by in vitro drug sensitivity testing for patients with cancer. J Clin Oncol 1999; 17: 1625-1631

12 Butler MS. Natural products to drugs: natural product derived compounds in clinical trials. Nat Prod Rep 2005; 22: 162-195 (Erratum: Nat Prod Rep 2006; 23: 131)

13 Newman DJ, Cragg GM. Natural products as sources of new drugs over the last 25 years. J Nat Prod 2007; 70: 461-477

14 Efferth T. Willmar Schwabe Award 2006: antiplasmodial and antitumor activity of artemisinin - from bench to bedside. Planta Med 2007; 73: 299-309

15 Efferth T, Fu YJ, Zu YG, Schwarz G, Konkimalla VS, Wink M. Molecular target-guided tumor therapy with natural products derived from traditional Chinese medicine. Curr Med Chem 2007; 14: 2024-2032

16 Efferth T, Li PC, Konkimalla VS, Kaina B. From traditional Chinese medicine to rational cancer therapy. Trends Mol Med 2007; 13: 353-361

17 Collins I, Workman P. New approaches to molecular cancer therapeutics. Nat Chem Biol 2006; 2: 689-700 (Erratum: Nat Chem Biol 2007; 3: 126)

18 Jain KK. Challenges of drug discovery for personalized medicine. Curr Opin Mol Ther 2006; 8: 487-492

19 Daly AK. Individualized drug therapy. Curr Opin Drug Discov Devel 2007; 10: 29-36

20 Fujita K, Sasaki Y. Pharmacogenomics in drug-metabolizing enzymes catalyzing anticancer drugs for personalized cancer chemotherapy. Curr Drug Metab 2007; 8: 554-562

21 Garman KS, Nevins JR, Potti A. Genomic strategies for personalized cancer therapy. Hum Mol Genet 2007; 16: R226-R232

22 Sikora $K$. Personalized medicine for cancer: from molecular signature to therapeutic choice. Adv Cancer Res 2007; 96: 345-369

23 Gunawan B, Huber W, Holtrup M, von Heydebreck A, Efferth T, Poustka A, Ringert $R H$, Jakse $G$, Füzesi L. Prognostic impacts of cytogenetic findings in clear cell renal cell carcinoma: gain of 5q31-qter predicts a distinct clinical phenotype with favorable prognosis. Cancer Res 2001; 61: 7731-7738

24 Trent JM. Cytogenetics of human malignant melanoma. Cancer Metastasis Rev 1991; 10: 103-113

25 Darling JL, Warr TJ, Ashmore SM, Luxsuwong M, Revesz T. Non-isotopic molecular cytogenetics in neuro-oncology. Neuropathol Appl Neurobiol 1997; 23: 441-456 
26 Adeyinka A, Mertens F, Idvall I, Bondeson L, Ingvar C, Heim S, Mitelman F, Pandis $N$. Cytogenetic findings in invasive breast carcinomas with prognostically favourable histology: a less complex karyotypic pattern? Int J Cancer 1998; 79: 361-364

27 Skapek SX, Chui CH. Cytogenetics and the biologic basis of sarcomas. Curr Opin Oncol 2000; 12: 315-322

28 Risques RA, Ribas M, Peinado MA. Assessment of cumulated genetic alterations in colorectal cancer. Histol Histopathol 2003; 18: 1289-1299

29 Akervall J. Gene profiling in squamous cell carcinoma of the head and neck. Cancer Metastasis Rev 2005; 24: 87-94

30 Campbell LJ. Cytogenetics of lymphomas. Pathology 2005; 37: 493-507

31 Keen-Kim D, Nooraie F, Rao PN. Cytogenetic biomarkers for human cancer. Front Biosci 2008; 13: 5928-5949

32 Panani AD. Cytogenetic and molecular aspects of gastric cancer: clinical implications. Cancer Lett 2008; 266: 99-115

33 Harrison CJ. Cytogenetics of paediatric and adolescent acute lymphoblastic leukaemia. Br J Haematol 2009; 144: 147-156

34 Efferth T, Verdorfer I, Miyachi H, Sauerbrey A, Drexler HG, Chitambar CR, Haber M, Gebhart E. Genomic imbalances in drug-resistant T-cell acute lymphoblastic CEM leukemia cell lines. Blood Cells Mol Dis 2002; 29: $1-13$

35 Gebhart E, Thoma K, Verdorfer I, Drexler HG, Efferth T. Genomic imbalances in T-cell acute lymphoblastic leukemia cell lines. Int J Oncol 2002; 21: 887-894

36 Ramirez T, Thoma K, Taja-Chayeb L, Efferth T, Herrera LA, Halatsch ME, Gebhart E. Specific patterns of DNA copy number gains and losses in eight new glioblastoma multiforme cell lines. Int J Oncol 2003; 23: 453-460

37 Patmore HS, Cawkwell L, Stafford ND, Greenman J. Unraveling the chromosomal aberrations of head and neck squamous cell carcinoma: a review. Ann Surg Oncol 2005; 12: 831-842

38 Liehr T, Ries J, Wolff E, Fiedler W, Dahse R, Ernst G, Steininger H, Koscielny $S$, Girod S, Gebhart E. Gain of DNA copy number on chromosomes 3q26qter and 5p14-pter is a frequent finding in head and neck squamous cell carcinomas. Int J Mol Med 1998; 2: 173-179

39 Gebhart E, Ries J, Wiltfang J, Liehr T, Efferth T. Genomic gain of the epidermal factor receptor harbouring band $7 \mathrm{p} 12$ is part of a complex pattern of genomic imbalances in oral squamous cell carcinomas. Arch Med Res 2004; 34: 385-394

40 Konkimalla VB, Suhas VL, Chandra NR, Gebhart E, Efferth T. Diagnosis and therapy of oral squamous cell carcinoma. Expert Rev Anticancer Ther 2007; 7: 317-329

41 Yan PS, Efferth T, Chen HL, Lin J, Rödel F, Fuzesi L, Huang TH. Use of CpG island microarrays to identify colorectal tumors with a high degree of concurrent methylation. Methods 2002; 27: 162-169

42 Iacopetta B, Kawakami K, Watanabe T. Predicting clinical outcome of 5fluorouracil-based chemotherapy for colon cancer patients: is the CpG island methylator phenotype the 5-fluorouracil-responsive subgroup? Int J Clin Oncol 2008; 13: 498-503

43 Sachidanandam R, Weissman D, Schmidt SC, Kakol JM, Stein LD, Marth G, Sherry S, Mullikin JC, Mortimore BJ, Willey DL, Hunt SE, Cole CG, Coggill $P C$, Rice CM, Ning Z, Rogers J, Bentley DR, Kwok PY, Mardis ER, Yeh RT, Schultz B, Cook L, Davenport R, Dante M, Fulton L, Hillier L, Waterston RH, McPherson JD, Gilman B, Schaffner S, Van Etten WJ, Reich D, Higgins J, Daly MJ, Blumenstiel B, Baldwin J, Stange-Thomann N, Zody MC, Linton L, Lander ES, Altshuler D, International SNP Map Working Group. A map of human genome sequence variation containing 1.42 million single nucleotide polymorphisms. Nature 2001; 409: 928-933

44 Botstein D, Risch $N$. Discovering genotypes underlying human phenotypes: past successes for Mendelian disease, future approaches for complex disease. Nat Genet 2003; 33: 228-237

45 Carlson CS, Eberle MA, Rieder MJ, Smith JD, Kruglyak L, Nickerson DA. Additional SNPs and linkage-disequilibrium analyses are necessary for whole-genome association studies in humans. Nat Genet 2003; 33: 518-521

46 Risch $N$. The genetic epidemiology of cancer: interpreting family and twin studies and their implications for molecular genetic approaches. Cancer Epidemiol Biomarkers Prev 2001; 10: 733-741

47 Efferth T. The human ATP-binding cassette transporter genes: from the bench to the bedside. Curr Mol Med 2001; 1: 45-65

48 Gottesman MM, Fojo T, Bates SE. Multidrug resistance in cancer: role of ATP-dependent transporters. Nat Rev Cancer 2002; 2: 48-58

49 Gillet JP, Efferth T, Remacle J. Chemotherapy induced resistance by ATPbinding cassette transporter genes. Biochem Biophys Acta 2007; 1775: 237-262
50 Efferth T, Osieka R. Clinical relevance of the MDR-1 gene and its gene product, P-glycoprotein, for cancer chemotherapy: a meta-analysis. Tumor Diagn Ther 1993; 14: 238-243

51 Sauerbrey A, Zintl F, Volm M. P-glycoprotein and glutathione S-transferase pi in childhood acute lymphoblastic leukaemia. Br J Cancer 1994; 70: 1144-1149

52 Volm M, Mattern J, Stammler G, Royer-Pokora B, Schneider S, Weirich A, Ludwig $R$. Expression of resistance-related proteins in nephroblastoma after chemotherapy. Int J Cancer 1995; 63: 193-197

53 Trock BJ, Leonessa F, Clarke R. Multidrug resistance in breast cancer: a meta-analysis of MDR1/gp170 expression and its possible functional significance. J Natl Cancer Inst 1997; 89: 917-931

54 Marie JP, Legrand O. MDR1/P-GP expression as a prognostic factor in acute leukemias. Adv Exp Med Biol 1999; 457: 1-9

55 Mahadevan D, List AF. Targeting the multidrug resistance-1 transporter in AML: molecular regulation and therapeutic strategies. Blood 2004; 104: 1940-1951

56 Hoffmeyer S, Burk O, von Richter O, Arnold HP, Brockmöller J, Johne A, Cascorbi I, Gerloff T, Roots I, Eichelbaum M, Brinkmann U. Functional polymorphisms of the human multidrug-resistance gene: multiple sequence variations and correlation of one allele with P-glycoprotein expression and activity in vivo. Proc Natl Acad Sci USA 2000; 97: 34733478

57 Ameyaw MM, Regateiro F, Li T, Liu X, Tariq M, Mobarek A, Thornton N, Folayan GO, Githang'a J, Indalo A, Ofori-Adjei D, Price-Evans DA, McLeod HL. MDR1 pharmacogenetics: frequency of the C3435T mutation in exon 26 is significantly influenced by ethnicity. Pharmacogenetics $2001 ; 11: 217-221$

58 Schwab M, Eichelbaum M, Fromm MF. Genetic polymorphism of the human MDR1 drug transporter. Annu Rev Pharmacol Toxicol 2003; 43: 285-307

59 Honda T, Dan Y, Koyabu N, Ieiri I, Otsubo K, Higuchi S, Ohtani H, Sawada $Y$. Polymorphism of MDR1 gene in healthy Japanese subjects: a novel SNP with an amino acid substitution (Glu108Lys). Drug Metab Pharmacokinet 2004; 17: 479-481

60 Sakaeda T, Nakamura T, Okumura K. Pharmacogenetics of MDR1 and its impact on the pharmacokinetics and pharmacodynamics of drugs. Pharmacogenomics 2003; 4: 397-410

61 Sakaeda T, Nakamura T, Horinouchi M, Kakumoto M, Ohmoto N, Sakai T, Morita Y, Tamura T, Aoyama N, Hirai M, Kasuga M, Okumura K. MDR1 genotype-related pharmacokinetics of digoxin after single oral administration in healthy Japanese subjects. Pharm Res 2001; 18: 1400-1404

62 Goh BC, Lee SC, Wang LZ, Fan L, Guo JY, Lamba J, Schuetz E, Lim R, Lim HL, Ong $A B$, Lee HS. Explaining interindividual variability of docetaxel pharmacokinetics and pharmacodynamics in Asians through phenotyping and genotyping strategies. J Clin Oncol 2002; 20: 3683-3690

63 Illmer T, Schuler US, Thiede C, Schwarz UI, Kim RB, Gotthard S, Freund D, Schäkel $U$, Ehninger G, Schaich M. MDR1 gene polymorphisms affect therapy outcome in acute myeloid leukemia patients. Cancer Res 2002; 62: 4955-4962

64 Kim RB. MDR1 single nucleotide polymorphisms: multiplicity of haplotypes and functional consequences. Pharmacogenetics 2002; 12: 425427

65 Kurata $Y$, Ieiri I, Kimura M, Morita T, Irie S, Urae A, Ohdo S, Ohtani H, Sawada Y, Higuchi S, Otsubo K. Role of human MDR1 gene polymorphism in bioavailability and interaction of digoxin, a substrate of P-glycoprotein. Clin Pharmacol Ther 2002; 72: 209-221

66 Efferth T, Sauerbrey A, Steinbach D, Gebhart E, Drexler HG, Miyachi H, Chitambar CR, Becker CM, Zintl F, Humeny A. Analysis of single nucleotide polymorphism C3435T of the multidrug resistance gene MDR1 in acute lymphoblastic leukemia. Int J Oncol 2003; 23: 509-517

67 Humeny A, Rödel F, Rödel C, Sauer R, Füzesi L, Becker C, Efferth T. MDR1 single nucleotide polymorphism C3435T in normal colorectal tissue and colorectal carcinomas detected by MALDI-TOF mass spectrometry. Anticancer Res 2003; 23: 2735-2740

68 Plasschaert SL, Groninger E, Boezen M, Kema I, de Vries EG, Uges D, Veerman AJ, Kamps WA, Vellenga E, de Graaf SS, de Bont ES. Influence of functional polymorphisms of the MDR1 gene on vincristine pharmacokinetics in childhood acute lymphoblastic leukemia. Clin Pharmacol Ther 2004; 76: 220-229

69 Gillet JP, Efferth T, Steinbach D, Hamels J, de Longueville F, Bertholet V, Remacle J. Microarray-based detection of multidrug resistance in human tumor cells by expression profiling of ATP-binding cassette transporter genes. Cancer Res 2004; 64: 8987-8993 
70 Steinbach D, Gillet JP, Sauerbrey A, Gruhn B, Dawczynski K, Bertholet V, de Longueville F, Zintl F, Remacle J, Efferth T. ABCA3 as a possible cause of drug resistance in childhood acute myeloid leukemia. Clin Cancer Res 2006; 12: 4357-4363

71 Efferth T, Gillet JP, Sauerbrey A, Zintl F, Bertholet V, de Longueville F, Remacle J, Steinbach D. Expression profiling of ATP-binding cassette transporters in childhood T-cell acute lymphoblastic leukemia. Mol Cancer Ther 2006; 5: 1986-1994

72 Volm M, Koomägi R, Mattern J, Efferth T. Protein expression profiles indicative for drug resistance of non-small cell lung cancer. Br J Cancer 2002; 87: 251-257

73 Volm M, Koomägi R, Mattern J, Efferth T. Expression profile of genes in non-small cell lung carcinomas from long-term surviving patients. Clin Cancer Res 2002; 8: 1843-1848

74 Volm M, Koomägi R, Mattern J, Efferth T. Protein expression profile of primary human squamous cell lung carcinomas indicative of the incidence of metastases. Clin Exp Metastasis 2002; 19: 385-390

75 Kumar-Sinha C, Chinnaiyan AM. Molecular markers to identify patients at risk for recurrence after primary treatment for prostate cancer. Urology 2003; 62 (Suppl. 1): 19-35

76 Talwalkar JA, Gores GJ. Diagnosis and staging of hepatocellular carcinoma. Gastroenterology 2004; 127 (5 Suppl. 1): S126-S132

77 Cai Z, Chiu JF, He QY. Application of proteomics in the study of tumor metastasis. Genomics Proteomics Bioinformatics 2004; 2: 152-166

78 Everley PA, Zetter BR. Proteomics in tumor progression and metastasis. Ann NY Acad Sci 2005; 1059: 1-10

79 Taylor BS, Varambally S, Chinnaiyan AM. A systems approach to model metastatic progression. Cancer Res 2006; 66: 5537-5539

80 Marguiles AG, Klimberg VS, Bhattacharrya S, Gaddy D, Suva LJ. Genomics and proteomics of bone cancer. Clin Cancer Res 2006; 12: 6217s-6221s

81 Pardo M, Dwek RA, Zitzmann N. Proteomics in uveal melanoma research: opportunities and challenges in biomarker discovery. Expert Rev Proteomics 2007; 4: 273-286

82 Mathias RA, Simpson RJ. Towards understanding epithelial-mesenchymal transition: a proteomics perspective. Biochim Biophys Acta 2009; 1794: $1325-1331$

83 Goodison S, Urquidi V. Breast tumor metastasis: analysis via proteomic profiling. Expert Rev Proteomics 2008; 5: 457-467

84 Efferth T, Rücker G, Falkenberg M, Manns D, Olbrich A, Fabry U, Osieka R. Detection of apoptosis in KG-1a leukemic cells treated with investigational drugs. Arzneimittelforschung 1996; 46: 196-200

85 Konkimalla VB, Efferth $T$. Evidence-based Chinese medicine for cancer therapy. J Ethnopharmacol 2008; 116: 207-210

86 Efferth T. Mechanistic perspectives for 1,2,4-trioxanes in anti-cancer therapy. Drug Resist Updat 2005; 8: 85-97

87 Efferth T. Molecular pharmacology and pharmacogenomics of artemisinin and its derivatives in cancer cells. Curr Drug Targets 2006; 7: 407421

88 Efferth T. Microarray-based prediction of cytotoxicity of tumor cells to cantharidin. Oncol Rep 2005; 13: 459-463

89 Efferth T, Kaina B. Microarray-based prediction of cytotoxicity of tumor cells to arsenic trioxide. Cancer Genomics Proteomics 2004; 1: 363370

90 Efferth T, Oesch F. Oxidative stress response of tumor cells: microarraybased comparison between artemisinins and anthracyclines. Biochem Pharmacol 2004; 68: 3-10

91 Efferth T, Dunstan H, Sauerbrey A, Miyachi H, Chitambar CR. The antimalarial artesunate is also active against cancer. Int J Oncol 2001; 18: 767-773

92 Efferth T, Olbrich A, Sauerbrey A, Ross DD, Gebhart E, Neugebauer M. Activity of ascaridol from the anthelmintic herb Chenopodium anthelminticum L. against sensitive and multidrug-resistant tumor cells. Anticancer Res 2002; 22: 4221-4224

93 Efferth T, Davey M, Olbrich A, Rücker G, Gebhart E, Davey R. Activity of drugs from traditional Chinese medicine toward sensitive and MDR1or MRP1-overexpressing multidrug-resistant human CCRF-CEM leukemia cells. Blood Cells Mol Dis 2002; 28: 160-168

94 Efferth T, Olbrich A, Bauer R. mRNA expression profiles for the response of human tumor cell lines to the antimalarial drugs artesunate, arteether, and artemether. Biochem Pharmacol 2002; 64: 617-623

95 Efferth T, Sauerbrey A, Halatsch ME, Ross DD, Gebhart E. Molecular modes of action of cephalotaxine and homoharringtonine from the coniferous tree Cephalotaxus hainanensis in human tumor cell lines. Naunyn Schmiedebergs Arch Pharmacol 2003; 367: 56-67
96 Efferth T, Sauerbrey A, Olbrich A, Gebhart E, Rauch P, Weber HO, Hengstler JG, Halatsch ME, Volm M, Tew KD, Ross DD, Funk JO. Molecular modes of action of artesunate in tumor cell lines. Mol Pharmacol 2003; 64: 382-394

97 Efferth T, Briehl MM, Tome ME. Role of antioxidant genes for the activity of artesunate against tumor cells. Int J Oncol 2003; 23: 1231-1235

98 Efferth T, Benakis A, Romero MR, Tomicic M, Rauh R, Steinbach D, Häfer $R$, Stamminger T, Oesch F, Kaina B, Marschall M. Enhancement of cytotoxicity of artemisinins toward cancer cells by ferrous iron. Free Radic Biol Med 2004; 37: 998-1009

99 Efferth T, Ramirez T, Gebhart E, Halatsch ME. Combination treatment of glioblastoma multiforme cell lines with the anti-malarial artesunate and the epidermal growth factor receptor tyrosine kinase inhibitor OSI-774. Biochem Pharmacol 2004; 67: 1689-1700

100 Efferth T, Chen Z, Kaina B, Wang G. Molecular determinants of response of tumor cells to berberine. Cancer Genomics Proteomics 2005; 2 : $115-124$

101 Efferth T, Rauh R, Kahl S, Tomicic M, Böchzelt H, Tome ME, Briehl MM, Bauer R, Kaina B. Molecular modes of action of cantharidin in tumor cells. Biochem Pharmacol 2005; 69: 811-818

102 Efferth T, Volm M. Glutathione-related enzymes contribute to resistance of tumor cells and low toxicity in normal organs to artesunate. In Vivo 2005; 19: 225-232

103 Dell'Eva R, Pfeffer U, Vene R, Anfosso L, Forlani A, Albini A, Efferth T. Inhibition of angiogenesis in vivo and growth of Kaposi's sarcoma xenograft tumors by the anti-malarial artesunate. Biochem Pharmacol 2004; 68: 2359-2366

104 Rinner B, Siegl V, Pürstner P, Efferth T, Brem B, Greger H, Pfragner R. Activity of novel plant extracts against medullary thyroid carcinoma cells. Anticancer Res 2004; 24: 495-500

105 Berger TG, Dieckmann D, Efferth T, Schultz ES, Funk JO, Baur A, Schuler $G$. Artesunate in the treatment of metastatic uveal melanoma - first experiences. Oncol Rep 2005; 14: 1599-1603

106 Adams M, Efferth T, Bauer R. Activity-guided isolation of scopoletin and isoscopoletin, the inhibitory active principles towards CCRF-CEM leukaemia cells and multidrug resistant CEM/ADR5000 cells from $\mathrm{Ar}$ temisia argyi. Planta Med 2006; 72: 862-864

107 Anfosso L, Efferth T, Albini A, Pfeffer U. Microarray expression profiles of angiogenesis-related genes predict tumor cell response to artemisinins. Pharmacogenomics J 2006; 6: 269-278

$108 \mathrm{Fu}$ YJ, Efferth T, Zu YG. Optimization of luteolin separation from pigeonpea [Cajanus cajan(L.) Millsp.] leaves by macroporous resins. J Chromatogr A 2006; 1137: 145-152

109 Fu Y, Zu Y, Zhang L, Zhang L, Tong M, Efferth T, Kong Y, Hou C, Chen L. Determination of vitexin and isovitexin in pigeonpea using ultrasonic extraction followed by LC-MS. J Sep Sci 2008; 31: 268-275

110 Wang J, Zheng Y, Efferth T, Wang R, Shen Y, Hao X. Indole and carbazole alkaloids from Glycosmis montana with weak anti-HIV and cytotoxic activities. Phytochemistry 2005; 66: 697-701

111 Wang YF, Cao JX, Efferth T, Lai GF, Luo SD. Cytotoxic and new tetralone derivatives from Berchemia floribunda (Wall.) Brongn. Chem Biodivers 2006; 3: 646-653

112 Wang YF, Lai GF, Efferth T, Cao JX, Luo SD. New glycosides from Tetracentron sinense and their cytotoxic activity. Chem Biodivers 2006; 3: 1023-1030

113 Efferth T, Marschall M, Wang X, Huong SM, Hauber I, Olbrich A, Kronschnabl M, Stamminger T, Huang ES. Antiviral activity of artesunate towards wild type, recombinant, and ganciclovir-resistant human cytomegaloviruses. J Mol Med 2002; 80: 233-242

114 Kaptein SJ, Efferth T, Leis M, Rechter S, Auerochs S, Kalmer M, Bruggeman $C A$, Vink $C$, Stamminger T, Marschall $M$. The anti-malaria drug artesunate inhibits replication of cytomegalovirus in vitro and in vivo. Antiviral Res 2006; 69: 60-69

115 Romero MR, Efferth T, Serrano MA, Castaño B, Macias RI, Briz O, Marin $\mathrm{JJ}$. Effect of artemisinin/artesunate as inhibitors of hepatitis B virus production in an "in vitro" replicative system. Antiviral Res 2005; 68 : 75-83

116 Romero MR, Serrano MA, Vallejo M, Efferth T, Alvarez M, Marin IJ. Antiviral effect of artemisinin from Artemisia annua against a model member of the Flaviviridae family, the bovine viral diarrhoea virus (BVDV). Planta Med 2006; 72: 1169-1174

117 Volm M, Wagner-Pommerenke E, Efferth T, Löhrke H, Mattern J. Circumvention of multidrug-resistance in human kidney and kidney carcinoma in vitro. Cancer 1991; 67: 2484-2489 
118 Cairns P, Polascik TJ, Eby Y, Tokino K, Califano J, Merlo A, Mao L, Herath J, Jenkins R, Westra W, Rutter JL, Buckler A, Gabrielson E, Tockman M, Cho $K$, Hedrick L, Bova GS, Isaacs W, Koch W, Schwab D, Sidransky D. Frequency of homozyous deletion at p16/CDKN2 in primary human tumours. Nat Genet 1995; 11: 210-212

119 Nobori T, Takabayashi K, Tran P, Orvis L, Batova A, Yu AL, Carson DA. Genomic cloning of methylthioadenosine phosphorylase: a purine metabolic enzyme deficient in multiple different cancers. Proc Natl Acad Sci USA 1996; 93: 6203-6208

120 Sherr CJ. The ink4a/arf network in tumour suppression. Nat Rev Mol Cell Biol 2001; 2: 731-737

121 Della Ragione F, Russo G, Oliva A, Mastropietro S, Mancini A, Borrelli A, Casero RA, Iolascon A, Zappia V. 5'-Deoxy-5'-methylthioadenosine phosphorylase and p16INK4 deficiency in multiple tumor cell lines. Oncogene 1995; 10: 827-833

122 Katamani N, Nelson-Rees WA, Carson DA. Selective killing of human malignant cell lines deficient in methylthioadenosine phosphorylase, a purine metabolic enzyme. Proc Natl Acad Sci USA 1981; 78: 12191223

123 Efferth T, Miyachi H, Drexler HG, Gebhart E. Methylthioadenosine phosphorylase as target for chemoselective treatment of T-cell acute lymphoblastic leukemic cells. Blood Cells Mol Dis 2002; 28: 47-56

124 Efferth T, Gebhart E, Ross DD, Sauerbrey A. Identification of gene expression profiles predicting tumor cell response to L-alanosine. Biochem Pharmacol 2003; 66: 613-621

125 Efferth T, Konkimalla VB, Wang YF, Sauerbrey A, Meinhardt S, Zintl F, Mattern J, Volm M. Prediction of broad spectrum resistance of tumors towards anti-cancer drugs. Clin Cancer Res 2008; 14: 2405-2412

126 Konkimalla VB, Efferth T. Anti-cancer natural product library from traditional Chinese medicine. Comb Chem High Throughput Screen 2008; 11: 7-15

127 Nobilit S, Landini I, Giglioni B, Mini E. Pharmacological strategies for overcoming multidrug resistance. Curr Drug Targets 2006; 7: 861879

128 Takara K, Sakaeda T, Okumura K. An update on overcoming MDR1mediated multidrug resistance in cancer chemotherapy. Curr Pharm Des 2006; 12: 273-286

129 Adams M, Mahringer A, Kunert O, Fricker G, Efferth T, Bauer R. Cytotoxicity and p-glycoprotein modulating effects of quinolones and indoloquinazolines from the Chinese herb Evodia rutaecarpa. Planta Med 2007; 73: 1554-1557

130 Adams M, Mahringer A, Bauer R, Fricker G, Efferth T. In vitro cytotoxicity and P-glycoprotein modulating effects of geranylated furocoumarins from Tetradium daniellii. Planta Med 2007; 73: 1475-1478

131 Majumder S, Dutta P, Mukherjee P, Datta ER, Efferth T, Bhattacharya S, Choudhuri SK. Reversal of drug resistance in P-glycoprotein-expressing T-cell acute lymphoblastic CEM leukemia cells by copper $\mathrm{N}$-(2-hydroxy acetophenone) glycinate and oxalyl bis( $N$-phenyl)hydroxamic acid. Cancer Lett 2006; 244: 16-23

132 Mookerjee A, Basu JM, Majumder S, Chatterjee S, Panda GS, Dutta P, Pal S, Mukherjee P, Efferth T, Roy S, Choudhuri SK. A novel copper complex induces ROS generation in doxorubicin resistant Ehrlich ascitis carcinoma cells and increases activity of antioxidant enzymes in vital organs in vivo. BMC Cancer 2006; 6: 267
133 Mookerjee A, Mookerjee Basu J, Dutta P, Majumder S, Bhattacharyya S, Biswas J, Pal S, Mukherjee P, Raha S, Baral RN, Das T, Efferth T, Sa G, Roy $S$, Choudhuri SK. Overcoming drug-resistant cancer by a newly developed copper chelate through host-protective cytokine-mediated apoptosis. Clin Cancer Res 2006; 12: 4339-4349

134 Weiss J, Rose J, Storch CH, Ketabi-Kiyanvash N, Sauer A, Haefeli WE, Efferth $T$. Modulation of human BCRP (ABCG2) activity by anti-HIV drugs. J Antimicrob Chemother 2007; 59: 238-245

135 Perea S, Hidalgo M. Predictors of sensitivity and resistance to epidermal growth factor receptor inhibitors. Clin Lung Cancer 2004; 6: S30S34

136 Lee CS, deFazio A, Ormandy CJ, Sutherland RL. Inverse regulation of oestrogen receptor and epidermal growth factor receptor gene expression in MCF-7 breast cancer cells treated with phorbol ester. J Steroid Biochem Mol Biol 1996; 58: 267-275

137 Wood ER, Truesdale AT, McDonald OB, Yuan D, Hassell A, Dickerson SH, Ellis B, Pennisi C, Horne E, Lackey K, Alligood KJ, Rusnak DW, Gilmer TM, Shewchuk $L$. A unique structure for epidermal growth factor receptor bound to GW572016 (Lapatinib), relationships among protein conformation, inhibitor off-rate, and receptor activity in tumor cells. Cancer Res 2004; 64: 6652-6659

138 Bremnes RM, Veve R, Gabrielson E, Hirsch FR, Baron A, Bemis L, Gemmill RM, Drabkin HA, Franklin WA. High-throughput tissue microarray analysis used to evaluate biology and prognostic significance of the E-cadherin pathway in non-small-cell lung cancer. J Clin Oncol 2002; 20: $2417-2428$

139 Nawrocki S, Skacel T, Brodowicz T. From microarrays to new therapeutic approaches in bladder cancer. Pharmacogenomics 2003; 4: 179189

140 Rich JN, Hans C, Jones B, Iversen ES, McLendon RE, Rasheed BK, Dobra A, Dressman HK, Bigner DD, Nevins JR, West M. Gene expression profiling and genetic markers in glioblastoma survival. Cancer Res 2005; 65: 4051-4058

141 Crijns AP, Duiker EW, de Jong S, Willemse PH, van der Zee AG, de Vries EG. Molecular prognostic markers in ovarian cancer: toward patienttailored therapy. Int J Gynecol Cancer 2006; 16 (Suppl. 1): 152-165

142 Seigneuric R, Starmans MH, Fung G, Krishnapuram B, Nuyten DS, van Erk A, Magagnin MG, Rouschop KM, Krishnan S, Rao RB, Evelo CT, Begg $A C$, Wouters BG, Lambin P. Impact of supervised gene signatures of early hypoxia on patient survival. Radiother Oncol 2007; 83: 374-382

143 Tan BK, Tan LK, Yu K, Tan PH, Lee M, Sii LH, Wong CY, Ho GH, Yeo AW, Chow PK, Koong HN, Yong WS, Lim DT, Ooi LL, Soo KC, Tan P. Clinical validation of a customized multiple signature microarray for breast cancer. Clin Cancer Res 2008; 14: 461-469

144 Chanrion M, Negre V, Fontaine H, Salvetat N, Bibeau F, Mac Grogan G, Mauriac L, Katsaros D, Molina F, Theillet C, Darbon JM. A gene expression signature that can predict the recurrence of tamoxifen-treated primary breast cancer. Clin Cancer Res 2008; 14: 1744-1752

145 Wooster R. Cancer classification with DNA microarrays. Is less more? Trends Genet 2000; 16: 327-329

146 Gillet JP, Schneider J, Bertholet V, de Longueville F, Remacle J, Efferth T. Microarray expression profile of $\mathrm{ABC}$ transporters in human breast cancer. Cancer Genomics Proteomics 2006; 3: 97-106

147 Volm M, Efferth T, Mattern J. Oncoprotein (c-myc, c-erbB1, c-erbB2, cfos) and suppressor gene product (p53) expression in squamous cell carcinomas of the lung. Clinical and biological correlations. Anticancer Res 1992; 12: 11-20 